$$
\begin{aligned}
& \text { Loyola Law School - Los Angeles } \\
& \text { Legal Studies Research Paper Series } \\
& \text { Paper No. 2010-04 }
\end{aligned}
$$

University of Southern California, Gould School of Law USC CLEO Research Paper Series

Paper No. C10-3

$$
\sim \text { and }
$$

University of Southern California, Marshall School of Business Research Paper No. FBE 28.10

\title{
Aggressive Enforcement of the Single Subject Rule
}

\author{
John G. Matsusaka \\ University of Southern California - Marshall School of Business; \\ USC Gould School of Law
}

Richard L. Hasen

Loyola Law School Los Angeles 


\title{
Aggressive Enforcement of the Single Subject Rule
}

\author{
John G. Matsusaka and Richard L. Hasen ${ }^{*}$ \\ February 8, 2010
}

\begin{abstract}
Most states require voter initiatives to embrace only a single subject, and courts have invalidated many initiatives for violating the single subject rule. Critics argue that the definition of a "subject" is infinitely malleable, and therefore, if judges attempt to enforce the single-subject rule aggressively, their decisions will be based on their personal views rather than neutral principles. We investigate this argument by studying the decisions of state appellate court judges in five states during the period 1997-2006. We find that judges are more likely to uphold an initiative against a single subject challenge if their partisan affiliations suggest they would be sympathetic to the policy proposed by the initiative. More important, we find that partisan affiliation is extremely important in states with aggressive enforcement of the single subject rule — the rate of upholding an initiative jumps from 42 percent to 83 percent when a judge agrees with the policy than when he disagrees — but not very important in states with restrained enforcement. The evidence suggests that it may be possible to apply the single subject rule in a neutral way if enforcement is approached with a deferential perspective, but with aggressive enforcement decisions are likely to driven by the political preferences of judges.
\end{abstract}

\footnotetext{
* John G. Matsusaka is the Charles F. Sexton Chair in American Enterprise at the Marshall School of Business, Gould School of Law, and Department of Political Science, University of Southern California. Richard L. Hasen is the William H. Hannon Distinguished Professor of Law at Loyola Law School, Los Angeles. Brief portions of this Article first appeared in Richard L. Hasen, Ending Court Protection of Voters from the Initiative Process, 116 YALE L.J. POCKET PART 117 (2006). Thanks to Dan Lowenstein for helpful comments, and Alex Chen, Jennifer Johnson, Vince Sheng, and Inna Zazulevskaya for diligent research assistance. This Article was prepared for delivery at "The Past, Present, and Future of Election Law: A Symposium Honoring the Work of Daniel Hays Lowenstein,” UCLA School of Law, January 29, 2009.
} 


\section{Introduction}

The single subject rule, on the books in at least 14 initiative states, requires that initiatives embrace only one subject. ${ }^{1}$ This paper studies the decisions of state judges in cases in which opponents of voter initiatives raised single subject claims. Courts used the rule to strike down or remove initiatives from voter consideration in at least 70 cases during the period 1997-2006 in five initiative states applying the rule. ${ }^{2}$

The single subject rule is particularly controversial because the definition of a “single subject” is unclear, and, as Dan Lowenstein has argued, it is infinitely malleable in theory. ${ }^{3}$ As a result, judges have a great deal of discretion in single subject cases, unless courts put meaningful restraints on judicial interpretation of the rule. Because of the discretion inherent in deciding single subject challenges, critics have argued that the rule is incapable of being enforced in an objective manner, and should not be used (Hasen 2006; Campbell 2001: 163), or, as Lowenstein (1983, 2002) argues, it should be used only in a very restrained manner. Defenders have responded that the rule is amenable to objective application, and that in practice judges have not allowed their personal beliefs to influence their decisions. ${ }^{4}$

Inspired by Lowenstein's analysis of the dangers of aggressive enforcement of the single-subject rule, this paper investigates single subject rulings in five key initiative states over a 10-year period to determine the extent to which partisan inclinations, career

\footnotetext{
${ }^{1}$ The 14 states are Alaska, Arizona, California, Colorado, Florida, Missouri, Montana, Nebraska, Nevada, Ohio, Oklahoma, Oregon, Washington, and Wyoming. See Waters (2003) for more information. Downey (2004) and Dubois and Feeney (1998) have somewhat different counts (see Part II.A below), but these discrepancies are not important for purposes of this Article. Each of the authors agree that the five states under study here-California, Colorado, Florida, Oregon, and Washington—-have a single subject rule applicable to voter initiatives.

2 See Part IV below.

${ }^{3}$ Lowenstein (2002, 47): “The difficulty of applying the term 'subject' in a single subject rule . . is that by its very nature, the permissible content of a 'subject' is infinitely and essentially malleable.”

${ }^{4}$ For example, Gilbert (2006, p. 810) proposes the following definition: “A bill can be said to embrace but one subject when all of its components command majority support due to their individual merits or legislative bargaining and the title gives notice of the bill's contents.” Gilbert and Cooter (2010) propose a “separable preference” principle for applying the single subject rule that they argue can be applied neutrally. Gilbert (2009) argues that judges do in fact apply a neutral principle.
} 
concerns, and other factors that should be irrelevant in deciding single-subject challenges play a role in judicial decisions. Our main finding is that decisions in single subject cases are heavily influenced by a judge's partisan inclinations, but that the amount of partisan influence depends on whether the state's judicial precedent directs judges to apply the single-subject rule aggressively or with restraint. Specifically, in a sample of 157 cases during the period 1997-2006, we find that in states with aggressive enforcement judges voted to uphold an initiative 83 percent of the time when it proposed a policy congruent with their partisan leanings but voted to uphold only 42 percent of the time when an initiative proposed a policy at odds with their partisan leanings. In contrast, in states with restrained enforcement judges upheld 88 percent of congruent cases and 81 percent of noncongruent cases.

This evidence provides strong support for Lowenstein's argument that aggressive enforcement is inevitably subjective:

Because "subjects" are chosen for convenience, notions of what forms a coherent subject in politics and legislation will depend in part on ideologies and "worldviews.” When judges apply the single subject rule aggressively, even if they seek to do so in accord with their sense of what the public understanding is, they will inevitably be exercising their own judgments in the most general way about what makes good political or policy sense. That is not to say that their single subject rule judgments will necessarily turn on whether they personally favor the proposals before them. But their judgments will necessarily reflect the way they have chosen to subjectively organize the world. (Lowenstein 2002: 47-48)

The evidence suggests that in practice the way judges subjectively organize the world is closely linked to their political ideologies, causing their single subject decisions to be strongly connected to their political views concerning the policy proposed by the initiative.

In addition to its relevance for understanding initiatives and the single subject rule, our study speaks to broader issues related to judicial behavior, discretion, and the rule of law. At the heart of the rule of law is the idea that judges make decisions based on 
general rules rather than to achieve particular policy outcomes. Rule-based decisions create predictability in the legal system, which is conducive to enterprise, and provide a form of equality before the law, which is essential for justice. ${ }^{5}$ This idea is central to the legal model of judging, which holds that decisions should be impartial, objective, unrelated to a judge's personal experiences and attitudes, and driven by legal doctrine and rules (Heise 2002). Unfortunately, empirical legal scholars have unearthed a great deal of evidence that is inconsistent with the legal model. Well known examples include Cross and Tiller (1998), Revesz (1997), and Sisk et al.(1998). In particular, numerous studies have found that partisan attitudes influence judicial decisions, mainly for federal judges, leading to what is sometimes called the behavioral or political model of judging (Heise 2002). Our study contributes to this body of knowledge by showing the importance of partisan affiliation in the context of state decisions. In contrast to most previous research, which finds measurable but modest effects of partisanship, we find effects that are quite large in magnitude.

Public choice scholars have advanced another model of judging that posits decisions are driven by career concerns of judges. (See Posner (1993) and McNollgast (1995) for theoretical arguments.) For example, in the federal context, judges may tailor their decisions to appeal to the President in order to increase their chances of appointment to a higher court. The public choice model is supported by a large empirical literature showing that judges decide differently when they must stand for re-election compared to when they are independent of the voters. (For examples, see Hanssen (1999), La Porta et al. (2004), Klerman and Mahoney (2005), and Lim (2008).) In all of the states we study, judges face periodic elections. A judge who rules against a voter initiative runs the risk of being accused of behaving anti-democratically when he or she stands for re-election,

\footnotetext{
${ }^{5}$ Hayek (1960: 208): "There is probably no single factor which has contributed more to the prosperity of the West than the relative certainty of the law which has prevailed here.” Page 214: "[T]he essence of the rule of law that the private citizen and his property should not ... be means at the disposal of government. Where coercion is to be used only in accordance with general rules, the justification of every particular act of coercion must derive from such a rule. To ensure this, there must be some authority which is concerned only with the rules and not with any temporary aims of government." Page 218: "Judicial forms are intended to insure that decisions will be made according to rules and not according to the relative desirability of particular ends or values.”
} 
which could imperil his or her prospects of remaining in office. To assess the importance of career concerns, we examine if judges behave differently when they are about to face the voters than when their next election is many years distant, and if they behave differently when they are on the verge of retirement than when they have many years of judging ahead of them. Consistent with the idea that career concerns matter, we find evidence that younger judges were less likely to strike down an initiative than older judges who were closer to retirement. However, we fail to find statistically significant evidence that behavior is different when a judge is about to stand for re-election than when an election is many years away, which is inconsistent with the public choice model. In both cases, the magnitude of the career concern effects is not large.

These findings taken together have two implications for the question of what can be done to minimize the role of partisanship in judicial decisions and increase objectivity. In terms of external solutions, our evidence suggests that increasing judicial accountability or reducing judicial independence through re-elections is not likely to help. There is even a countervailing danger with frequent elections that judges may replace one form of bias (the judge's partisan leanings) with another (catering to the majority of the electorate). In terms of internal solutions, some scholars have suggested that judges should be encouraged to become more self-aware or self-conscious of the influence of political attitudes on their decisions. (For example, Sisk (2000: 211).) That seems a worthwhile aspiration, but may not be a realistic solution since the danger of partisan influence has been known for some time yet still appears in the data. Our finding that judicial bias is severe with aggressive enforcement but modest with restrained enforcement suggests a different possible approach, through the use of a decisionmaking principle or "canon" of interpretation that begins with deference to the initiative. ${ }^{6}$

If courts approach the single subject rule with a restrained rather than aggressive approach, our evidence suggests that the role of partisan leanings will be sharply minimized. We believe our evidence demonstrating that the role of partisanship is strongly connected to the degree of aggressiveness in enforcement of a law is novel, and at the most general level, raises the question whether aggressive judging is likely to be

\footnotetext{
${ }^{6}$ On the role of canons of constructions applicable in interpreting direct democracy legislation, see Frickey (1996) and Eskridge et al. (2007).
} 
more prone to partisan decisionmaking than restrained judging in other contexts. ${ }^{7}$ In terms of the single subject rule itself, our evidence suggests that the most effective way to promote objectivity may be to adopt a restrained approach rather than to seek additional interpretive "tests" that operationalize the concept of a single subject.

This Article proceeds as follows. Part II gives background on the single subject rule in law and theory. Part III reviews the little empirical evidence that others have collected to this point on judicial application of the single subject rule. Part IV presents the evidence from our new empirical study. Part V discusses the implications of our study for the single subject rule.

\section{The Single Subject Rule in Law and Theory}

\section{A. Law}

At least thirteen of the twenty-two states allowing initiated statutes and eleven of the eighteen states allowing initiated constitutional amendments provide that no initiated measure presented to the voters shall contain more than a single subject. (Dubois and Feeney 1998; Downey 2004.) Some of these states further provide that each constitutional amendment put before voters be subject to a "separate vote."8 A court determining that an initiated measure contains more than one subject will often remove it from the ballot or declare the measure void if it has already been enacted; some courts consider the less drastic step of severing the measure, and placing only part of it before voters. ${ }^{9}$

\footnotetext{
${ }^{7}$ Whether aggressive enforcement leads to partisan decisionmaking in other contexts remains to be seen. The crux of the problem with the single subject rule is the malleability of the concept of a "subject" and it is the act of trying to define a subject that seems to open the door for partisanship. An aggressive approach that rejected almost every initiative without grappling with the notion of a "subject" could also be relatively immune to partisan influences.

${ }^{8}$ Lowenstein (2002) explores the separate vote cases in detail, and explains how some courts with restrained enforcement of the single subject rule have adopted aggressive enforcement of the separate vote requirement to achieve the same result as aggressive enforcement of the single subject rule. In this Article, we analyze single subject and separate vote requirements together, and we discuss both requirements simply as the "single subject rule."

${ }^{9}$ See, e.g., Nevadans for the Prot. of Prop. Rights v. Heller, 141 P.3d 1235, 1245-46 (Nev. 2006).
} 
Table 1 reports the single subject language in the five initiative states we study. The language is similar though not identical across states, but in every case depends on the meaning of the term "subject." The term "subject” is not self-defining, and therefore courts must specify the appropriate standard for counting the number of subjects in an initiative. As Dan Lowenstein pithily put it,

[S]uppose I am giving a lecture and I announce at the outset that my subject will be the battle of Antietam, the contributions made to health by vitamin C, and Shakespeare's The Merchant of Venice. You would undoubtedly find it a surprising subject, but you could not say in advance that it is not a subject....[N]o combination of matters can be ruled out in advance as a single subject. Defining a subject is purely and essentially a matter of convenience. (Lowenstein 2002: 47.)

Single-subject litigation during the 2006 election season shows the potential for arbitrary outcomes when courts apply a single subject rule. Consider two proposed initiatives and ask yourself if either, or both, violate the single-subject rule:

Initiative A shifts responsibility for drawing state legislative and congressional districts from the state legislature to a redistricting commission. The commission must draw single-member districts, changing current practice which allows multi-member districts for the state legislature.

Initiative $B$ limits marriage to one man and one woman. It also prevents localities from adopting “civil unions” for non-married couples that would give those in such unions any of the rights of married couples.

In two opinions issued on the same day in March 2006, the Florida Supreme Court struck down Initiative A and upheld Initiative B against single-subject challenges. ${ }^{10}$ As to the redistricting measure, the court ruled that federal redistricting and state redistricting are separate subjects, and both differ from the use of single-member

\footnotetext{
${ }^{10}$ Advisory Opinion to the Attorney Gen. Re: Indep. Nonpartisan Comm'n To Apportion Legislative and Cong. Dists. Which Replaces Apportionment by Legislature, 926 So.2d 1218 (Fla. 2006) [hereinafter Redistricting Case]; Advisory Opinion to the Attorney Gen. Re: Fla. Marriage Prot. Amendment, 926 So.2d 1229 (Fla. 2006).
} 
districts. ${ }^{11}$ As to the marriage proposal, the court held that both parts of the measure dealt with the subject of marriage. ${ }^{12}$

It is not hard to imagine other courts reaching different conclusions. Indeed, some have. A California court upheld an election reform measure much more disparate than the Florida redistricting measure against a single-subject challenge. ${ }^{13}$ A state court in Georgia struck down a measure very similar to Initiative $B$ on grounds that same-sex marriage and civil unions are separate subjects ${ }^{14}$ (a decision later reversed by the Georgia Supreme Court). ${ }^{15}$

In his 1983 article, Lowenstein traced the history of California's single subject rule applicable to initiatives. ${ }^{16}$ He noted the two main approaches to single-subject adjudication in the state, a liberal or restrained interpretation (under which most single subject challenges to initiatives should be rejected) requiring that the different provisions of the initiative be "reasonably germane” to one another to be upheld, and a more stringent or aggressive interpretation (under which more single subject challenges to initiatives would succeed) requiring that the different provisions of the initiative be "functionally related" to one another. California has opted for the "reasonably germane" test, and California's courts traditionally have rejected most single subject challenges. In 2002, Lowenstein wrote a second article on the single subject rule, lamenting what he saw as newly-aggressive enforcement of the rule in many states, including in California.

Each state has developed its own single-subject jurisprudence and linguistic glosses on the rule, and it is not our purpose here to provide a detailed exegesis of these states’ glosses. ${ }^{17}$ Florida, for example, has earned a reputation as a state with aggressive

\footnotetext{
${ }^{11}$ See Redistricting Case, 926 So.2d at 1225-26.

12 Advisory Opinion to the Attorney Gen. Re: Fla. Marriage Prot. Amendment, 926 So.2d 1229 (Fla. 2006).

${ }^{13}$ Fair Political Practices Comm’n v. Superior Court, 599 P.2d 46, 47-48 (Cal. 1979).

${ }^{14}$ O’Kelley v. Perdue, No. 2004CV93494, 2006 WL 1350171 (Ga. Super. Ct. May 16, 2006), rev’d, 632 S.E.2d 110 (Ga. 2006).

${ }^{15}$ Perdue v. O’Kelley, 632 S.E.2d 110, 113 (Ga. 2006).

${ }^{16}$ A similar rule applies to legislation passed by the state legislature as well, but that is not within the scope of Lowenstein's subject, or ours.

${ }^{17}$ For detailed analysis, see Lowenstein, Hasen, and Tokaji (2008: 382-394).
} 
enforcement of the rule (Miller 2009: 182), requiring that all parts of an initiative have a zen-like "logical and natural oneness of purpose"18 in order to steer clear of a single subject violation. The Florida Supreme Court relied on this test in striking down the redistricting initiative described above: “A voter who advocates apportionment by a redistricting commission may not necessarily agree with the change in the standards for drawing the legislative and congressional districts. Conversely, a voter who approves the change in district standards may not want to change from the legislative apportionment process currently in place. Thus, a voter would be forced to vote in the 'all or nothing' fashion that the single subject requirement safeguards against." ${ }^{19}$ Because a voter would be required to make this choice, the Florida high court held, the measure did not have a “oneness of purpose,” and it therefore violated the single subject rule.

Regardless of the verbal formulation of the test, and whether or not the test requires aggressive or restrained implementation, courts typically have identified two potential interests served by the single-subject rule: prevention of logrolling and avoiding voter confusion. ${ }^{20}$ It is to these interests we now turn.

\section{B. Theory}

The theoretical underpinnings of the single subject rule are remarkably weak. As Lowenstein (1983, pt. III) observes, the two most common rationales for the single subject rule are (1) to prevent logrolling, and (2) to prevent voter confusion. This section briefly sketches the main theoretical issues, most of which have been explored at greater length in the existing literature, as indicated throughout.

\section{Logrolling}

Logrolling may be undesirable if it subverts the electorate's will. However, theoretically it is not necessarily the case that logrolling does subvert the electorate, and there are clearly situations where allowing logrolling can lead to outcomes more

\footnotetext{
${ }^{18}$ Redistricting Case, at 1225.

${ }^{19}$ Redistricting Case, at 1226.

${ }^{20}$ See, e.g., Redistricting Case, at 1225 (recognizing anti-logrolling purpose); Californians for an Open Primary v. McPherson, 134 P.3d 299, 336 (Cal. 2006) (noting interest in avoiding voter confusion and stating that "Voter confusion occurs when, for example, numerous provisions are included in a single ballot measure, thereby making it unclear that voters actually are aware of all the provisions they are voting on.”).
} 
consonant with the majority's preferences. That logrolling can be beneficial in some situations has been recognized by public choice scholars at least back to Buchanan and Tullock (1962). Here we provide a brief recap of the argument (see also Kousser and McCubbins (2005) and Gilbert (2006)).

One concern with logrolling is that by combining two "projects," one that is good and one that is bad, the voters will be forced to adopt the bad project against their interests (what Lowenstein (1983) calls a "rider”). To see the limits of this argument, consider the following hypothetical situation:

\section{Project A Project B}

Adopted

Not adopted

\begin{tabular}{|c|c|}
\hline 2 & -1 \\
\hline 0 & 0 \\
\hline
\end{tabular}

There are two projects, $\mathrm{A}$ and $\mathrm{B}$, where A delivers the voters a utility payoff of 2 if adopted and zero otherwise, while B delivers a payoff of -1 if adopted and zero otherwise. Clearly, if voted on separately, A would pass and B would fail.

If the two are bundled into a single proposition, voters would receive a payoff of 1 by approving the bundle, and zero by rejecting the bundle. The bundled measure would then pass. It is not clear why this is a problem. The voters are better off with the bundle than without it, which is why they approved it in the first place. It is true that voters would be better off if they had the opportunity to vote on the projects separately rather than as a package, but nothing guarantees this would happen if the package is not allowed. Indeed, when a court strikes down a measure on single subject grounds, it does not give voters the opportunity to vote on the separate pieces, but rather forces rejection of both projects, which in this case is not optimal.

A different configuration would be the following:

\section{Project A Project B}

\begin{tabular}{c|c|c|}
\cline { 2 - 3 } Adopted & 2 & -3 \\
\cline { 2 - 3 } Not adopted & 0 & 0 \\
\cline { 2 - 3 } & &
\end{tabular}


Here the bad project is really bad. As before, in a separate vote, project A would be approved, and project B would fail. If the voters were forced to decide on a bundle of A and B, they would reject the bundle (preferring the default payoff of zero to the bundle payoff of -1). In this case, there is no need for intervention by a court because voters will reject the package on their own. It could be argued that voters lack the ability to discern the payoffs of the different elements of the package, but this argument speaks more to the validity of the entire direct democracy enterprise than the single subject rule. In order to ask voters to make policy decisions, it seems necessary to grant that they have a basic competence in recognizing their own interests.

The two preceding examples indicate that if the second option is not too bad, a single subject rule will prevent the voters from adopting a package that makes them better off than not having the package, while if the second option is very bad, the voters will reject the bundle on their own. At best, the single subject rule is redundant; at worst, it is harmful.

The concern is deepened once we recognize that it may be possible to approve some valuable projects only through a bundle (what Lowenstein (1983) calls “coalitionbuilding”). Consider the following situation, with three voters.

\begin{tabular}{l|c|c|c|c|c|c|} 
& \multicolumn{2}{c}{ Voter 1 } & \multicolumn{2}{c}{ Voter 2 } & \multicolumn{3}{c}{ Voter 3 } \\
A & A & B & A & B & A & B \\
\cline { 2 - 8 } Nopted & 100 & -1 & -1 & 100 & -1 & -1 \\
\cline { 2 - 8 } Not adopted & 0 & 0 & 0 & 0 & 0 & 0 \\
\cline { 2 - 8 } & & &
\end{tabular}

In this case, voter 1 enjoys very high benefits from project $A$ and is mildly hurt by project B; voter 2 enjoys very high benefits from project B and is mildly hurt by project A; and voter 3 is mildly hurt by both projects. If we count the welfare of each person equally, the socially optimal choice is to approve both projects: project A produces a net gain of 98 as does project B.

If the projects are decided separately, both will fail: voters 2 and 3 will vote against project $\mathrm{A}$, and voters 1 and 3 will vote against project $\mathrm{B}$. If the projects are bundled, then both will pass: voter 1 will support the package (the gain of 100 from A 
offsets the loss of 1 from B); voter 2 will support the package (the gain of 100 from B offsets the loss of 1 from A); and voter 3 will vote no. Allowing the projects to be bundled brings about the socially optimal outcome. In this situation, enforcement of a single subject rule will make it impossible to achieve the optimal outcome. (As an aside, critics of direct democracy often celebrate the give and take of legislatures as compared to the one-shot nature of ballot propositions. It should be recognized that legislatures rely extensively on logrolls to implement their agreements. Indeed, without the ability to logroll it is hard to imagine how complicated legislative bargains could be struck and enforced.) $)^{21}$

The previous example is not intended to suggest that logrolling is always beneficial. To the contrary, there are also situations where a logroll can bring about a socially undesirable outcome, such as the following:

\begin{tabular}{l|c|c|c|c|c|c|}
\multicolumn{1}{c}{} & \multicolumn{2}{c}{ Voter 1 } & \multicolumn{2}{c}{ Voter 2 } & \multicolumn{2}{c}{ Voter 3 } \\
\multirow{3}{*}{$\begin{array}{l}\text { Adopted } \\
\text { Not adopted }\end{array}$} & 3 & -1 & -1 & 3 & -10 & -10 \\
\cline { 2 - 7 } & 0 & 0 & 0 & 0 & 0 & 0 \\
\hline
\end{tabular}

Here the socially optimal course is to reject both measures. If they are voted on separately, both will fail. If they are voted on as a package, however, the package will pass, with voters 1 and 2 in support.

To be clear, the point here is not that logrolls are always beneficial but rather that logrolls can be good and bad. Much of the doctrine and analysis surrounding the single subject rule presumes that logrolls are always bad, and voters need to be protected against

\footnotetext{
${ }^{21}$ Our discussion here does not consider the case where the projects are interrelated in some way, as might be the case with a proposal to build a new train station and a new rail line. Forcing separate votes on possibly connected issues could lead to poor public decisions. See the discussion in Kousser and McCubbins (2005, page 961), and their criticism of the single subject rule on precisely these grounds.
} 
all logrolls. ${ }^{22}$ As we have seen, this view is overly simplistic, lacks theoretical justification, and stands a real chance of inhibiting socially desirable policy changes.

\section{Voter Confusion}

Another alleged purpose of the single subject rule is to prevent voter confusion. (Dubois and Feeney 1998: 148.) The issue of voter competence has been a central concern in thinking about direct democracy for as long as the process has been around, and it is well recognized that voters must have access to information to make wise decisions (Lupia and Matsusaka, 2004). Contrary to simple intuitions, empirical research suggests that citizens are able to vote in a sophisticated manner if they have access to endorsements and other "information cues” (Lupia, 1994; Lupia and McCubbins, 1998). Be that as it may, it is difficult to see the single subject rule as a vehicle for reducing complexity and alleviating voter confusion. We cannot improve on Dan Lowenstein's brief-yet-effective argument:

The rule is ill-suited to prevent voter confusion because no matter how the rule is construed, it will bar some initiatives that are simple and permit others that are hopelessly complex. Consider, for example, an initiative containing two provisions: (1) change the date of the primary election from June to May; and (2) increase the maximum sentence for the crime of rape by one year. While most people would regard it as odd for these two and only these two provisions to be combined in one initiative, and while the measure would presumably violate the single-subject rule, it would also be one of the simplest and most easily understood initiatives ever proposed in California. On the other hand, one can easily imagine a proposal that would contain extensive but more or less technical revisions in a single, specialized area—say, school finance-that could not be

\footnotetext{
${ }^{22}$ For example, Gilbert and Cooter (2010) describe the premise of the single subject rule to be: "bargaining in the initiative process is likely to be harmful and should be forbidden.” As we have shown, the theoretical argument can go either way, and we are not aware of any evidence that would justify the claim that logrolling in initiatives is "likely" to be harmful.
} 
understood thoroughly by anyone but a handful of experts, but that would satisfy the single-subject rule under any plausible construction.

It is no doubt true that, all else being equal, a measure with fewer provisions will be easier to understand than a measure with more provisions. All else is seldom equal, however, and in most cases the complexities of the individual provisions and of the general subject matter are likely to be far more significant factors in the measure's overall complexity than the mere number of provisions. Furthermore, the correlation between the diversity of the initiative's subject matter and the number of provisions is likely to be very weak. An outlandishly diverse measure could contain one simple provision per "“subject," whereas a unified measure could contain thousands of provisions. ${ }^{23}$

We also note that we are unaware of any empirical evidence that the single subject rule in practice has reduced complexity or alleviated voter confusion.

\section{Other Research on Judicial Application of the Single Subject Rule}

Empirical research on the single subject rule is extremely scarce. Kenneth $\mathrm{P}$. Miller (2009: ch. 4) examined single-subject challenges to voter-approved initiatives in five initiative states (Arizona, California, Colorado, Oregon, and Washington) during the period 1904-2008 as part of a larger study of court invalidation of voter-approved initiatives. Miller considered only challenges to voter-approved initiatives; he did not consider pre-election challenges, as are routine in Colorado and sometimes used in other states. Miller found a total of 7 cases in which there was a single subject or separate vote violation (Miller 2009: 116 tbl. 4.3.) but he did not go beyond this descriptive information to consider the factors that motivated judges to vote to uphold or reject an

\footnotetext{
${ }^{23}$ Lowenstein (1983:954-55, footnotes omitted). Given Lowenstein's rejection of both the anti-logrolling and anti-voter confusion arguments, it is somewhat puzzling why he does not simply reject the single subject rule outright (as opposed to calling simply for its liberal interpretation). According to Lowenstein, the liberal test should be used because it would block only outlier initiatives that went "beyond the intended scope of the initiative as an instrument of governance" toward "wholesale law revisions" Id. at 964. But on that basis, a cleaner rule would simply target revisions directly, rather than using the clumsy device of the single subject rule.
} 
initiative. Based on a rough survey of state use of the single subject rule in recent years, he concluded: "By the early 2000s the trend was clear: Courts in several initiative states were more strictly enforcing two technical rules, the single-subject rule and the separatevote requirement, as a constraint on the initiative power.” (Miller 2009: 184).

The most comprehensive and informative study of judicial behavior in single subject cases is Gilbert's (2009) analysis of California, Colorado, Florida, and Oklahoma between 1980 and 2007. The key part of his analysis is statistical evidence on the factors that explain the decision of judges in single subject cases. Gilbert includes variables that are intended to capture objective legal considerations as well as attitudinal variables that should not be relevant for decisions. For each case, he constructs what he considers "an objective measure of the number of subjects” by surveying UC-Berkeley undergraduate and law students. The students were given two principles to define the number of subjects — what he calls the "categorization subject count" and "democratic process subject count" - and asked to count the number of subjects in the initiatives that came before the courts in his sample. Gilbert finds that both subject count variables are correlated with the voting behavior of judges, meaning that the decisions of judges are to some extent associated with these underlying principles, at least as interpreted by the survey respondents. More important for our purposes, Gilbert constructs an index of each judge's “liberalness” based on the partisan makeup of the state's legislature at the time of the judge's appointment (following Brace et al. (2000)), and constructs an index of each initiative’s “liberalness” based on classifications by graduate students at UC-Berkeley. He finds that judges were more likely to uphold an initiative if the judge and the initiative both had a high liberalness score, or the judge and the initiative both had a low liberalness score, that is, if there was an affinity between the judge's presumed ideological orientation and the orientation of the initiative.

Using a statistical technique to compare the two explanatory factors - objective subject count and political affinity — Gilbert concludes that (2009: 51) "law trumps politics.” However, the method by which he reaches this conclusion (2009: 45-47) is not entirely satisfying. His approach is to use his estimated logit model to generate predicted probabilities of a judge finding a single subject violation for different values of the number of subjects and political affinity, holding the other explanatory variables at their 
mean values. He finds that a large swing in the number of subjects changes the predicted probability of a single subject violation more than a large swing in political affinity. While interesting and certainly not without value, this approach is limited in that it only involves predicted probabilities, not actual probabilities, and the predictions rely on the assumption that the estimated model accurately represents the process by which judges reach their decisions (that is, it assumes the model parameters are accurate). ${ }^{24}$

We follow Gilbert's analysis by considering the match between the content of the initiative and the judge's views, although we rely on more transparent measures. Rather than rely on predicted probabilities to assess the magnitude of impacts, we examine direct (nonparametric) estimates of the actual frequency that decisions are upheld conditional on political affinity. Perhaps the critical innovation of our study is to compare the impact of judge-initiative affinity in states with aggressive enforcement to the impact in states with deferential enforcement. Lowenstein's argument was not that single subject rules were incapable of being enforced in a neutral way, but that neutral enforcement was impossible if a state adopted an aggressive posture.

\section{New Evidence}

\section{A. Description of Data and Variables}

Our analysis is based on a sample of 157 single-subject cases decided during the decade 1997-2006 by the supreme and intermediate appellate courts in five major initiative states: California, Colorado, Florida, Oregon, and Washington. The cases were identified by Lexis and Westlaw searches in the state caselaw databases for cases decided by state appellate courts containing the words "single subject” or "separate vote.” We then examined the actual decisions to verify that a single subject challenge was in fact part of the case. For each case, we identified the participating justices and collected a variety of information on their personal characteristics, terms, and ideological orientation, as discussed below. We also collected information on the content of the initiatives that were under review. The key explanatory variables are discussed next:

\footnotetext{
${ }^{24}$ Logit models also incorporate sometimes subtle interactions between the explanatory variables that can sharply influence marginal effects.
} 
- Partisan orientation of judge. We are interested in understanding how often a judge's decision in a single subject case appears to be influenced by his or her view of the policy merit of the initiative under review. To that end, we classify each judge as either a Democrat or Republican. The judges in the states we study must all stand for re-election at some point, but the elections are nonpartisan, so we rarely have a judge's self-described political affiliation. Instead, we assign each judge to the party of the governor that first nominated him or her to the court. A few judges in the state of Washington won their seats in an open election rather than being appointed by a governor. For those judges, we assigned a party based on their past career (for example, a judge who previously held office in the state legislature was assigned his or her party from that period), endorsements and fundraising (for example, a judge who received funding primarily from Democratic groups was classified as a Democrat), and other miscellaneous information. For some judges, we were unable to discover any evidence suggesting a party affiliation, and they were dropped from the sample.

Assigning a partisan orientation to judges based on the party of the official appointing them has a long tradition in research on courts (Brace et al., 2000). We believe the transparency of this measure makes it better suited for our purposes than index approaches (such as the one developed by Brace et al. (2000) that imputes a continuous ideology score based on the relative strength of the parties in the judge's state in the year he or she was appointed). Our classification system is imperfect — indeed, casual observation of the U.S. Supreme Court makes it clear that the nominating president is not a perfect predictor of a justice's subsequent behavior — but to the extent that our classifications are wrong, the result will be to introduce noise into the estimates, biasing against finding evidence that a judge's partisan affiliation matters. That is, to the extent our classification system is crude, it will make it more difficult to find evidence of political motivations in judicial decisions.

There is an ongoing debate about the appropriate way to measure the ideology of a judge (Heise 2002), but for our purposes it is not important whether we are measuring the "true" preferences of the judge so much as whether our 
variable predicts voting behavior: if judges are applying the law in an objective way, their decisions should have no connection to the party of the official that appointed them. To the extent we find that our measure of partisanship matters, it undercuts the idea that the law is being applied objectively on the basis of neutral rules.

- Ideological orientation of initiative. A second important variable is the ideological orientation of the initiative being challenged. Since we are interested in knowing whether a judge is likely to be favorably or unfavorably inclined toward the policy proposed by the initiative, we attempt to classify each initiative as “conservative” or "liberal/progressive”. Such classifications are inherently subjective, but we think our choices are not overly controversial. Table 2 shows how we classified the different types of initiatives so the reader can form his or her own opinion about the validity of our measure. Some initiatives do not fit into an obvious left-right box, such as open primary laws and laws affecting the judiciary, and we assign those initiatives to a separate "other” category. Initiatives where the ideological classification seems arguable are noted with an asterisk in Table 2; in our empirical analysis, we estimate our model treating the asterisked initiatives in different ways to establish robustness. We recognize that this type of classification is simplistic, but again, to the extent that it incorporates error, it will only bias against finding any effects. As will be seen, even with our crude classification system, we find that partisanship explains a significant amount of voting behavior on single subject rulings.

- Career concerns. A large literature suggests that the behavior of judges, like that of other public officials, responds to their career concerns (for example, Hanssen, 1999; LaPorta et al., 2004; Klerman and Mahoney, 2005). If career concerns are important, we expect that judges would feel pressured by re-election considerations to uphold initiatives because voters strongly support the initiative process. Judges that strike down a popularly approved measure or remove a measure from the ballot without giving voters a chance to weigh in could be seen 
as anti-democratic, and pay a price at the polls. In all five states in our sample, judges must stand for re-election. The terms vary, ranging from a low of 6 years in Washington to a high of 12 years in California, and the type of election varies (such as open elections where anyone can run in Washington, and pure retention elections where only the incumbent judge's name is on the ballot in California). To test for the possibility that judges weigh the consequence of their votes on their career prospects, we construct two variables: the number of years until the judge's next election, and the age of the judge. If judges take into account career concerns when making decisions, a judge will be more likely to uphold an initiative when there are fewer years until his or her next election and when the judge is farther from retirement age (Florida has a mandatory retirement of 70 , Colorado has a mandatory retirement age of 72, and Oregon and Washington have a mandatory retirement age of 75 , but all judges anticipate retirement at some point).

- Number of words in initiative. One argument for the single subject rule is to reduce complexity of initiatives and minimize voter confusion (Dubois and Feeney 1998). Long initiatives are likely to be more complex, and a huge amount of text certainly serves as a barrier to voter understanding. For this reason, some reformers have argued that the number of words on an initiative should be limited, for example, the California Commission on Campaign Financing (1992) recommended a 5,000-word limit on all ballot propositions. To test if decisions reflected a concern with complexity, we collected data on the number of words in the initiative. If reducing complexity is an important factor in single subject rulings, we would expect judges to be more skeptical toward long initiatives than short initiatives. When a case reviewed more than one initiative at a time, we used the average number of words across the involved initiatives. There is a huge variation in the length of initiatives in our sample, ranging from 12 at the low end to almost 32,000 at the high end. The longest initiatives are clustered in California. 


\section{B. Summary Information on Judges}

Table 3 provides summary information on judges in the sample. Overall, our data set contains 778 votes on single subject cases. On average, 31 percent of the sample judges are classified as Republicans and 69 percent are classified as Democrats. In contrast, 56 percent of the initiatives under review are classified as conservative in their policy orientation compared to 24 percent that are classified as liberal (the remaining 20 percent do not have an obvious classification on a conservative-liberal spectrum). A typical case, then, consists of judges with Democratic leanings deciding on whether to allow a vote on an initiative that proposes a policy with a conservative bent.

To make this more concrete, we construct a variable called AGREE that takes on the value of one if the judge's partisan affiliation agrees with the initiative, and zero otherwise. That is, AGREE $=1$ if the judge is Republican and the initiative is conservative, or the judge is Democratic and the initiative is liberal/progressive. Across the sample, 42 percent of judges find themselves agreeing (in this sense) with the initiative under review, and 38 find themselves disagreeing.

The average age of sample judges is 56.5 years, with the youngest 41 years old and the oldest 87 years old. On average, a judge deciding on a single subject case faces election in 2.9 years, with some facing election in the year of the decision and others facing election 12 years in the future.

\section{Summary of Outcomes}

To provide context for the results that follow, we begin by summarizing the outcomes of the cases in the sample. Table 4 reports the frequency with which the initiatives were upheld by state and level of court. Consistent with California's reputation of deferential enforcement of the single subject rule, California courts upheld the initiative in question in 94 percent of cases during the sample period. Washington courts were also fairly accommodating, upholding in 91 percent of cases. Florida is usually considered to have strict enforcement, but its courts upheld initiatives against single subject challenges in 80 percent of cases. At the other end, Colorado courts upheld initiatives 50 percent of the time, and only 25 percent of initiatives were upheld in Oregon. It should be kept in mind that these approval numbers do not necessarily indicate 
the aggressiveness of enforcement. Even though Florida's approval rate is high, it could be that the courts there are so well known to enforce strictly that many initiatives never come to the ballot, and those that do, are carefully crafted to survive challenges. The numbers do suggest that there are state-specific forces at work, so our multivariate analysis will take that into account. ${ }^{25}$

Table 4 also shows that state supreme courts are much less likely to uphold an initiative against a single subject challenge than state intermediate appellate courts, 62 percent versus 91 percent. Indeed, the intermediate appellate courts almost always uphold initiatives in the face of single subject challenges across both deferential and strict states. This pattern, in part, is due to the fact that most decisions in California, a state that rarely finds single subject violations, are made at the intermediate appellate court level, so it is not clear if it reflects a general deference by lower level courts, or a California effect.

We also explored but do not separately report the trend in approval rates over time. Contrary to what might be expected based on Lowenstein (2002) and Miller (2009), the fraction of cases upheld against single subject challenge has not fallen over time. Indeed, if anything, courts are more likely to uphold initiatives against single subject challenges in the later than earlier years of our sample. ${ }^{26}$ Again, this does not necessarily indicate less aggressive enforcement over time: it could be that enforcement is becoming stricter, leading to fewer initiatives, but those that do appear are less likely to violate the rule. There could also be a delay in observing effects. Key decisions of a state supreme court could have a significant but lagged effect at the intermediate appellate courts.

\section{Unanimity}

Lowenstein (1983) argued that the single subject rule is impossible to enforce objectively due to the inherent subjectivity of the definition of a "subject." One way to

\footnotetext{
${ }^{25}$ The number of failed cases in states such as Colorado and Florida which allow pre-election review might be greater than in other states because initiative proponents sometimes submit variations of the same measure for approval to see which variations can survive single subject challenge.

${ }^{26}$ Unfortunately, this statement conceals a remarkable fact: while the percent of judges voting to approve was never less than 58 percent in nine of our ten sample years, it was only 8 percent in 1999. Exactly what happened in 1999 is a mystery that is beyond the scope of our study to answer.
} 
get a rough sense of the objectivity of single subject rulings is to examine the amount of agreement in decisions. If it is possible to determine objectively the number of subjects, and judges are applying the counting rule neutrally, decisions would be unanimous or nearly unanimous.

Table 5 reports the frequency of cases in which the decision was unanimous. For the sample as a whole, 80 percent of cases were unanimous, indicating that judges were able to agree on the proper outcome in a large majority of cases. The strongest agreement was in California (92 percent unanimous decisions) and Washington (85 percent unanimous decisions), where courts apply the single subject rule with deference to the initiative. In Colorado (75 percent), Florida (67 percent), and Oregon (67 percent), where enforcement is more aggressive, unanimous decisions were less common. Nevertheless, even in the most aggressive states, we still see at least two-thirds of the cases being decided unanimously.

The interpretation of the evidence in Table 5 is ambiguous. A high level of agreement could mean that judges have found neutral principles that are broadly shared. On the other hand, it could be that that these decisions are determined by partisan considerations, and that we see so much unanimity because courts are typically composed entirely of members of the same party. In our sample, the justices were all of the same party in 43 percent of cases, and homogeneous courts were 17 percent more likely to reach a unanimous decision. ${ }^{27}$ The next section examines the votes of individual judges for more direct evidence.

\section{E. Explaining the Votes of Individual Judges}

Our core evidence concerns the votes of individual judges. We are particularly interested in understanding to what extent a judge's views on the substantive policy implications of the initiative under review can explain his or her vote. To be clear, we are not asserting that any of the justices are deliberately deciding on the single subject issue in order to impose their policy views. Rather, we are investigating Lowenstein's (1983)

\footnotetext{
${ }^{27}$ A regression of unanimity on a dummy variable for courts consisting entirely of members of one party (parameters not reported) reveals that ideologically homogeneous courts are more likely to reach a unanimous decision.
} 
argument that because the single subject rule cannot be applied objectively, judges will be forced to introduce subjective considerations into their decision making, and the set of beliefs and philosophies that drive their party affiliation will come into play in their holding on the single subject rule. A critical implication of this view, which we test, is whether judges appear to rely more on their substantive policy preferences when the single subject rule is applied strictly as opposed to loosely.

Table 6 reports our central results, multivariate logistic regressions that estimate the probability that a judge votes to uphold an initiative. Each column reports estimates from a separate model, in which the dependent variable can be understood as an increasing (nonlinear) function of the probability that a judge votes to uphold. The variables listed are the explanatory factors. The main entries are the coefficient estimates, and the standard errors are in parentheses. A positive coefficient means that an increase in the variable increases the likelihood of upholding, and a negative coefficient means that an increase in the variable reduces the likelihood of upholding. ${ }^{28}$ Asterisks indicate coefficients that can be distinguished from noise at conventional levels of statistical significance. All regressions include indicator variables for California, Colorado, Florida, Oregon, Washington that allow for state-specific effects on the mean probability of approval, but we do not report the coefficients. ${ }^{29}$

The regression in column (1) of Table 6 includes as explanatory factors a variable for the number of words in the initiative, the year, and dummy variables for the states. The number of words is a crude indicator that might be expected to be correlated with the complexity of the initiative and/or the number of subjects; the year is included to allow for a trend in enforcement principles over time; and the state dummies capture differences in the individual state single subject laws. Because there are huge differences between states in the number of words (the average number of words in California is seven times the average in Washington and more than 20 times the average in the other states), a variable equal to the absolute number of words would capture primarily state effects rather than length effects. So we use instead a dummy variable equal to one if the

\footnotetext{
${ }^{28}$ Unfortunately, the actual coefficient estimates cannot be interpreted directly in terms of marginal changes in probabilities.

${ }^{29}$ Our main findings do not change in substance if the models are estimated without the state fixed effects.
} 
number of words is greater than the median number of words on initiatives that are reviewed in that state (and takes on a value of zero otherwise). The dummy variable for the number of words indicates whether the initiative under consideration is longer or shorter than the typical initiative reviewed in that state. ${ }^{30}$

The coefficient on the number of words is positive and significantly different from zero, indicating counterintuitively that judges are more likely to vote to uphold longer than shorter initiatives. As will be seen in the later columns, this coefficient loses significance when other explanatory variables are included, so the relation is apparently spurious, and not much should be made of the positive coefficient. However, the consistent failure to find evidence that judges reject long initiatives undercuts the view that the single subject rule is used to protect voters from complex measures. The coefficient on the year is also positive and significant, indicating that judges are increasingly likely to vote to uphold in the later than earlier years of our sample. This finding is robust to inclusion of other control variables, so does not appear to be spurious. Apparently, there has been a gradual trend toward upholding initiatives during our sample period. The unreported state dummies are significant and generally similar to each other.

The regression in column (2) of Table 6 adds explanatory variables that capture potential political considerations. The first new variable is a dummy for cases decided at the supreme court level, as opposed to the state's intermediate court of appeals. The negative and significant coefficient indicates that supreme court justices are less likely to uphold an initiative than intermediate appellate court justices, even controlling for state, year, number of words, and so on. A possible explanation for this pattern could be that lower-court judges have their eye on promotion to a higher court, and thus are less inclined to make decisions limiting the popular initiative process.

The next variable is the political affiliation of the judge, which takes on a value of one if the judge is a Republican and zero if the judge is a Democrat. As discussed above, these affiliations are based on the party of the governor who appointed the judge to the court, and in some cases, other information in the judge's background. The positive coefficient indicates that Republican judges are more likely to vote to uphold than

\footnotetext{
${ }^{30}$ We also find a significant positive coefficient when we use a variable that is simply the number of words.
} 
Democratic judges. We cannot say from these estimates if Republican judges are more accommodating because of a greater philosophy of deference, or because they are more likely to agree with the substance of the initiatives, but will turn to that question shortly.

A third variable added to column (2) reflects the ideological orientation of the initiative. The variable is equal to one if the initiative has a "conservative" orientation, and zero otherwise. We also include a variable equal to one if the initiative impacts the judiciary, such as term limits for judges. The estimates indicate that judges are significantly less likely to vote to uphold conservative initiatives and initiatives concerning the judiciary (compared to the omitted categories of "liberal/progressive" and "other" initiatives.) The fact that conservative initiative fare less well than other initiatives suggests that political factors are connected with a judge's decision on a particular case.

The regression in column (3) of Table 6 drills down into this issue by adding three new variables. The key variable is AGREE, which as discussed above takes on the value of one if the judge's partisan orientation agrees with the content of the initiative, and zero otherwise. As can be seen, agreement (so measured) is strongly and positively associated with the likelihood of voting to uphold an initiative against a single subject challenge. This is fairly direct evidence that single-subject decisions are not made neutrally, independent of a judge's substantive policy view of the initiative in question.

Gilbert (2009), using somewhat different methods, reports a similar finding in a partially overlapping sample. He assigns each judge a numerical value for partisanship and assigns each initiative a numerical value for ideological orientation. He finds that the likelihood of voting to uphold is positively related to the similarity in scores. Our results reinforce Gilbert's findings, and show that simple and fairly transparent partisan affiliations go a long way toward explaining voting behavior.

Once the agreement variable is included in the regression, the coefficient on the judge's partisan affiliation falls in magnitude (from 0.35 to 0.10 ) and is no longer statistically distinguishable from zero. This suggests that Democratic and Republican judges do not have a fundamentally or philosophically different approach to single subject rulings, and that the significant coefficient in column (2) was a spurious correlation reflecting the fact that Republican judges were more likely to be ruling on 
initiatives they liked while Democratic judges were more likely to be ruling on initiatives they disliked. The coefficient on the ideological orientation of the initiative also falls in magnitude and becomes statistically insignificant, but in other specifications it becomes significant again.

The regression in column (3) tests for career concerns by including two additional variables, the number of years until the judge's next election and the age of the judge (which is negatively related to the expected number of years before retirement). ${ }^{31}$ If career concerns are important, we expect that a judge will be more likely to uphold as an election draws near, producing a negative coefficient. Similarly, as a judge grows older and gets closer to retirement, he or she should become less concerned with re-election issues; because older judges would be less likely to cater by upholding an initiative, approval rates should be negatively associated with age.

The estimates for both career concerns variables take on the predicted negative sign, but only the age variable is significantly different from zero at the 10 percent level of significance. The voting behavior of judges is not reliably different when an election is close than when it is distant, but judges are less likely to uphold an initiative as they become older. Put differently, young judges are less likely to challenge the will of the voters by rejecting an initiative. This is not particularly strong evidence for career concerns.

The estimates in column (3) indicate that judges are more likely to uphold a case when they agree with the substance of the initiative, relative to a case where they disagree and a case where they are neutral (in the sense that the initiative does not have an obvious partisan orientation). Since there is some ambiguity about to interpret the cases that lack a partisan orientation, the regression in column (4) of Table 6 reports a regression with the same specification after deleting the nonpartisan initiatives. In this case, the coefficient on AGREE can be interpreted as the effect of agreement relative to the case of

\footnotetext{
${ }^{31}$ Because very long time periods to the next election can only occur in states with long terms, there is a danger that "years to next election” may be capturing state-specific effects. To adjust for this possibility, we truncate the variable at six years, that is, if the number of years to the next election is more than six years, we treat it as six years. It turns out that the results do not change in a material way with or without this adjustment.
} 
disagreement. As can be seen, the underlying picture remains the same: judges are more likely to uphold cases when they agree with the initiative than when they disagree with the initiative.

The evidence to this point suggests that a judge's policy preferences play a role in how he or she applies the single subject rule. Lowenstein's original argument is that this is an inevitable consequence of attempting to apply the rule aggressively: because it is impossible to apply the single subject rule strictly in an objective way, judges will be forced to introduce other considerations into the decision, and those considerations are likely to be correlated with their general world view that also shapes their partisan affiliation. The flip side of this, Lowenstein argues, is that if judges adopt a deferential or restrained approach to the single subject rule, they are more likely to be able to apply it objectively, and are less likely to rely on their subjective intuitions to make the decision.

Column (5) of Table 6 tests this proposition by allowing the effect of agreement to be different in "aggressive” states (states that are believed to apply the single subject rule strictly) and "restrained" states (states that tend to give the benefit of the doubt to the initiative in single subject rules). Following Lowenstein (2002), Miller (2009), and conventional wisdom, we classify California and Washington as restrained states, and Colorado, Florida, and Oregon as aggressive states. ${ }^{32}$ Lowenstein's argument suggests that subjective factors such as a judge's personal views will be more important in aggressive than deferential states. Consistent with this idea, column (5) shows that whether or not a judge agrees with the initiative policy is a strong predictor of his or her voting behavior in aggressive states. The coefficient on agreement in a state with aggressive enforcement is 0.93 and statistically different from zero at the 5 percent level, while the coefficient on agreement in a state with restrained enforcement is 0.26 and statistically insignificant. In words, decisions are strongly predicted by whether judges agree with the content of the initiative in aggressive states, but there is no relation in restrained states. $^{33}$

\footnotetext{
${ }^{32}$ Oregon arguably could be included in either group. Because there are relatively few observations from Oregon, the overall pattern of the results does not depend on how Oregon is classified.

${ }^{33}$ It appears that a large fraction of cases in our sample are frivolous challenges to two crime initiatives (Prop. 21 in California and I-159 in Washington) made by criminal defendants. To be sure crime initiatives
} 
The coefficients in Table 6 are difficult to interpret except in terms of the direction of the effects. To give a sense of the magnitude of the effects, Table 7 reports the raw percentage of votes to uphold, conditional on agreement and whether the state has an aggressive or deferential approach. In deference states, judges upheld the initiative 88.3 percent of the time when they agreed with it compared to 80.6 percent of the time when they disagreed. So we see that even in restrained states, judges are less likely to support an initiative they disagree with, but the effect is modest.

The case of states with aggressive enforcement is eye-opening. Judges upheld initiatives they agreed with 83.2 percent of the time in aggressive states, approximately the same approval rate as in deference states. However, in aggressive states, judges upheld initiatives they disagreed with only 42.1 percent of the time. Thus, in states with aggressive enforcement judges were 41.1 percent less likely to approve an initiative they disagreed with than an initiative they agreed with. This is a huge effect, and highlights the important role played by subjective considerations when courts attempt to apply the single subject rule strictly.

Table 7 also reports how judges voted on issues concerning the judiciary. In our sample, these initiatives mainly proposed to curtail the prerogatives of judges. In the aggressive states (the only states where such initiatives appeared in our sample), judges upheld these initiatives 54.8 percent of the time, again far below the percentage of time they voted to uphold initiatives they agreed with.

\section{Discussion}

The single subject requirement is a technical rule that is often used to invalidate voter initiatives, either before they go to the ballot, or after they are approved. The rule is controversial, with critics claiming that it cannot be enforced in an objective, consistent

are not driving our results, we reestimated the main results after deleting all crime initiatives. The findings did not change in any important way. We also explored including a number of other control variables, many of which have been used in the literature, including gender and ethnicity of the judge, legislative background, and academic background. See Sisk et al. (1998) for comparison. None of these variables had significant explanatory power or affected the main findings. Finally, we reestimated the regression in column (5) after deleting initiatives that one could argue are nonpartisan (those with asterisks in Table 2), and found very similar results. 
way because the definition of a "subject" is infinitely elastic. Our evidence, based on analysis of more than 500 judicial votes in single subject cases during the period 19972006 strongly supports these criticisms. We find that in states with aggressive enforcement of the single subject rule, decisions are well predicted by whether or not a judge is likely to agree with the substance of the initiative under review based on his or her partisan affiliation.

The finding that political preferences play a role in judicial decisions is not novel — a sizeable literature has established that point, and Gilbert (2009) has shown that political preferences play a role specifically in the context of single subject rulings. The novelty of our paper is, first, showing that the influence of a judge's political preferences grows as enforcement of the rule becomes more aggressive. This is precisely what Lowenstein (2002:48) argued: “Aggressive application of the single subject rule therefore necessarily entails a subjective, standardless veto on the part of judges of the sort that was rejected by the framers of the Constitution when they rejected the proposed Council of Revision. Only the deferential approach permits judges honestly to apply standards drawn from the public understanding rather than from their own subjective ways of organizing the world.” Our evidence provides clear support for the underlying mechanism that Lowenstein identified as problematic for enforcement of the single subject rule, and builds a normative case for a restrained or deferential approach to enforcing the rule.

A second novelty of our paper is the finding of a huge effect of political preferences on judicial decisions. While many previous studies have found a connection between a judge's political inclinations and his or her decisions, in most cases those effects have been modest. In contrast, we find that political inclinations play a huge, perhaps dominant role, in single subject decisions. When enforced aggressively, judges uphold initiatives that agree with their political preferences 83 percent of the time, while upholding initiatives that disagree with their political preferences only 42 percent of the time. There is a sense in some of the literature on judicial behavior that political preferences matter, but are small enough that they can be ignored in most cases. Our evidence shows one context where political factors appear to be central drivers of judicial 
decisions, and suggests they must be center stage in any appraisal of the single subject rule. $^{34}$

In terms of the single subject rule specifically, as noted above, our evidence strongly suggests that the rule has not been applied in a neutral way. Some defenders of the single subject rule, while acknowledging the potential dangers of decisionmaking to suit the policy preferences of judges, claim that the problem has not appeared in practice. ${ }^{35}$ Our evidence identifies a central role of political preferences in single subject decisions, at least in the five states and the period we study. Aggressive enforcement not only raises the bar, but significantly increases the role of political preferences in judging.

One limitation of our study is that we do not include controls for legal factors that might drive decisions (other than the number of words), and therefore we are not running a race between political and legal determinants of decisions (Gilbert, 2009). While it would be desirable to include more explanatory variables, we believe the possibility of omitted legal variables does not cast significant doubt on our findings. Our conclusions would be spurious if there is an omitted legal variable that persuades Democratic and Republican judges differently, and also happens to persuade them that there is a single subject violation primarily in cases where they dislike the underlying initiative, and also is more persuasive in states with aggressive than restrained enforcement. We cannot think of an obvious candidate for what such an omitted variable might be.

Another limitation of our study is the potential endogeneity of a state's decision to adopt an aggressive versus strict approach to enforcement. Because we do not know what caused one state to adopt an aggressive stance and another to adopt a restrained stance, we cannot rule out the possibility that some underlying factor in the state's political environment drives both the choice of aggressive enforcement and partisan judicial decisionmaking. If this was the case, it would not be aggressive enforcement itself that led to partisan decisions, but the unidentified factor. While we acknowledge this

\footnotetext{
${ }^{34}$ Of course, our results hold in a particular set of states and time period; it remains to be seen whether our findings hold for other states and other time periods. So some caution is in order when generalizing beyond our sample.

${ }^{35}$ Gilbert (2009, p. 5): “I find that law trumps politics. Judges apply the rule more objectively that most observers expect, although politics does matter.”
} 
possibility, the fact that there is a strong theoretical case for drawing a line of causality from aggressive enforcement to partisan decisions goes some way toward allaying the concern that our finding is entirely spurious.

The politicization of judging that accompanies aggressive enforcement of the single subject rule undermines the rule of law and leads to several potential problems. To the extent that decisions depend on the identity of the judges that hear a case, initiative sponsors will find it difficult to determine the legal validity of their proposals. The problem is especially acute at the intermediate appellate level where proponents face the possibility of their measure being challenged in any number of courts, with judges of widely varying partisan orientation. This form of judicial roulette acts as deterrent to the extent that proponents are risk averse, with the result that some proponents will choose to forgo the costs of an initiative campaign rather than face the uncertainty of judicial reversal. ${ }^{36}$ As a consequence, the electorate will end up with fewer options, and policy choices will be less congruent with the will of the majority. ${ }^{37}$ Lowenstein observes that a purpose of the single subject rule is to perfect the initiative process. Contrary to this purpose, subjective decisionmaking by judges will have the effect of inhibiting its use. Thus, politicization of the rule threatens to undermine the direct democracy process itself by discouraging citizen petitions. Another problem, noted by Lowenstein, is that political decisionmaking will be seen as arbitrary by citizens, thus undermining confidence in the judicial system. $^{38}$

For the same reason, our results suggest we should be pessimistic about efforts to discover a legal theory that could objectively discriminate between one and multiple

\footnotetext{
${ }^{36}$ See Lowenstein (1983, Section III(4)) for a discussion of the problems created for initiative proponents by aggressive enforcement.

${ }^{37}$ For theory and evidence that initiatives bring about policies more consonant with public opinion, see Gerber (1999), Matsusaka and McCarty (2001), and Matsusaka (2004, 2009). For surveys of recent research on direct democracy, see Lupia and Matsusaka (2004) and Matsusaka (2005).

${ }^{38}$ Hayek (1960, p. 219): “To use the trappings of judicial form where the essential conditions for a judicial decision are absent, or to give judges power to decide issues which cannot be decided by the application of rules, can have no effect but to destroy the respect for them even where they deserve it.” Lowenstein (1983) raises the issue of an erosion of public confidence in the judiciary with aggressive enforcement of the single subject rule.
} 
subjects. ${ }^{39}$ Experience strongly suggests that judges so far have been unable to settle on a doctrine that can be enforced in a neutral and consistent manner. Instead, our evidence suggests that neutrality and consistency would be better advanced by adoption of a restrained or deferential posture. As discussed by Lowenstein and elaborated above, we believe the dangers that the single subject rule is purported to address are exaggerated in any case, and the hope of alleviating these modest dangers is unlikely to outweigh the costs of aggressive enforcement.

${ }^{39}$ For recent efforts see Gilbert (2009) and Gilbert and Cooter (2010). 


\section{References}

Brace, Paul, Laura Langer, and Melinda Gann Hall, "Measuring the Preferences of State Supreme Court Judges,” Journal of Politics, May 2000, Vol. 62(2), 387-413.

Buchanan, James and Gordon Tullock, The Calculus of Consent: Logical Foundations of Constitutional Democracy, Ann Arbor: University of Michigan Press, 1962.

California Commission on Campaign Financing, Democracy by Initiative: Shaping California's Fourth Branch of Government, Los Angeles: Center for Responsive Government, 1992.

Campbell, Anne G., "In the Eye of the Beholder: The Single Subject Rule for Ballot Initiatives," in The Battle over Citizen Lawmaking: A Collection of Essays (M. Dane Waters ed., 2001) 131.

Cross, Frank B. and Emerson H. Tiller, “Judicial Partisanship and Obedience to Legal Doctrine: Whistleblowing on the Federal Court of Appeals,” Yale Law Journal, 1998, Vol. 107.

Downey, Rachael, et al., "A Survey of the Single Subject Rule as Applied to Statewide Initiatives,” Journal of Contemporary Legal Issues, 2004, Vol. 13, p. 579.

Dubois, Philip L. and Floyd Feeney, Lawmaking by Initiative: Issues, Options, and Comparisons, New York: Agathon Press, 1998.

Eskridge, William N. Jr., Philip P. Frickey, and Elizabeth Garrett, Cases and Materials on Legislation: Statutes and the Creation of Public Policy, Foundation/West Publishers (4 $4^{\text {th }}$ ed.), 2007.

Frickey, Philip P, “Interpretation on the Borderline: Constitutions, Canons, Direct Democracy,” 1996 Annual Survey of American Law 477.

Gerber, Elisabeth R., The Populist Paradox: Interest Group Influence and the Promise of Direct Legislation, Princeton University Press, 1999.

Gilbert, Michael D., "Single Subject Rules and the Legislative Process,” University of Pittsburgh Law Review, 2006, Vol. 67, 803-870.

Gilbert, Michael D., "How Much Does the Law Matter? Theory and Evidence from Single Subject Adjudication,” working paper, 2009, http://works.bepress.com/michael_d_gilbert/9/.

Gilbert, Michael D. and Robert D. Cooter, “A Theory of Direct Democracy and the Single Subject Rule,” Columbia Law Review, (forthcoming 2010). 
Hanssen, F. Andrew, “Appointed Courts, Elected Courts, and Public Utility Commissions: Judicial Independence and the Energy Crisis,” Business and Politics, April 1999, Vol. 1(2), 179-201.

Hasen, Richard L., "Ending Court Protection of Voters from the Initiative Process," Yale Law Journal Pocket Part, 2006.

Hayek, F. A., The Constitution of Liberty, University of Chicago Press, 1960.

Heise, Michael, “The Past, Present, and Future of Empirical Legal Scholarship: Judicial Decision Making and the New Empiricism,” University of Illinois Law Review, 2002, Vol. 4, 819-850.

Klerman, Daniel M. and Paul G. Mahoney, “The Value of Judicial Independence: Evidence from Eighteenth Century England,” American Law and Economics Review, 2005, Vol. 7(1), 1-27.

Kousser, Thad and Mathew D. McCubbins, "Social Choice, Crypto-Initiatives, and Policymaking by Direct Democracy,” Southern California Law Review, May 2005, Vol. 78(4), 949-984.

La Porta, Rafael, Florencio Lopez-de-Silanes, Cristian Pop-Eleches, and Andrei Shleifer, “Judicial Check and Balances,” Journal of Political Economy, April 2004, Vol. 112(2), 445-470.

Lim, Claire, "Turnover and Accountability of Appointed and Elected Judges,” working paper, Stanford Graduate School of Business, 2008.

Lowenstein, Daniel H., “California Initiatives and the Single-Subject Rule,” UCLA Law Review, June 1983, Vol. 30, 936-974.

Lowenstein, Daniel H., “Initiatives and the New Single Subject Rule,” Election Law Journal, 2002, Vol. 1(1), 35-48.

Lowenstein, Daniel Hays, Richard L. Hasen, and Daniel P. Tokaji. 2008. Election LawCases and Materials (4th ed. Carolina Academic Press).

Lupia, Arthur and John G. Matsusaka, "Direct Democracy: New Approaches to Old Questions,” Annual Review of Political Science, 2004.

Lupia, Arthur and Mathew D. McCubbins, The Democratic Dilemma: Can Citizens Learn What They Need to Know?, Cambridge University Press, 1998.

Matsusaka, John G., For the Many or the Few: The Initiative, Public Policy, and American Democracy, Chicago: University of Chicago Press, 2004. 
Matsusaka, John G., "Direct Democracy Works,” Journal of Economic Perspectives, 2005, Vol. 19(2), 185-206.

Matsusaka, John G., "Popular Control of Public Policy: A Quantitative Approach,” working paper, USC Marshall School of Business, 2009.

Matsusaka, John G. and Nolan M. McCarty, "Political Resource Allocation: Benefits and Costs of Voter Initiatives,” Journal of Law, Economics, and Organization, 2001, Vol. 17(2), 413-448.

McNollgast, "Politics and Courts: A Positive Theory of Judicial Doctrine and the Rule of Law,” Southern California Law Review, 1995, Vol. 68.

Miller, Kenneth P., Direct Democracy and the Courts, Cambridge University Press, 2009.

Posner, Richard A., "What Do Judges Maximize? (The Same Thing Everybody Else Does), Supreme Court Economic Review, 1993, Vol. 3.

Revesz, Richard L., "Environmental Regulation, Ideology, and the D.C. Circuit," Virginia Law Review, 1997, Vol. 83.

Sisk, Gregory C., “Judges Are Human, Too,” Judicature, 2000, Vol. 83.

Sisk, Gregory C., Michael Heise, and Andrew P. Morriss, "Charting the Influences on the Judicial Mind: An Empirical Study of Judicial Reasoning,” New York University Law Review, November 1998, Vol. 73(5), 1377-1500.

Waters, M. Dane, Initiative and Referendum Almanac, Durham, NC: Carolina Academic Press, 2003. 
Table 1. Single Subject Rules in Specific States

\begin{tabular}{|c|c|c|}
\hline State & Rule & Source \\
\hline California & $\begin{array}{l}\text { "An initiative measure embracing more } \\
\text { than one subject may not be submitted to } \\
\text { the electors or have any effect." }\end{array}$ & $\begin{array}{l}\text { California Constitution, } \\
\text { Article II, Section } 8 \text { (d) }\end{array}$ \\
\hline Colorado & $\begin{array}{l}\text { "No measure shall be proposed by } \\
\text { petition containing more than one } \\
\text { subject, which shall be clearly expressed } \\
\text { in its title ..." }\end{array}$ & $\begin{array}{l}\text { Colorado Constitution } \\
\text { Article V, Section } 1 \text { (5.5) }\end{array}$ \\
\hline Florida & $\begin{array}{l}\text { “...any ... revision or amendment, except } \\
\text { for those limiting the power of } \\
\text { government to raise revenue, shall } \\
\text { embrace but one subject and matter } \\
\text { directly connected therewith.” }\end{array}$ & $\begin{array}{l}\text { Florida Constitution, Article } \\
\text { XI, Section } 3\end{array}$ \\
\hline Oregon & $\begin{array}{l}\text { "A proposed law or amendment to the } \\
\text { Constitution shall embrace one subject } \\
\text { only and matters properly connected } \\
\text { therewith." }\end{array}$ & $\begin{array}{l}\text { Oregon Constitution, } \\
\text { Article IV, Section } 1 \text { (2d) }\end{array}$ \\
\hline Washington & $\begin{array}{l}\text { "No bill shall embrace more than one } \\
\text { subject, and that shall be expressed in the } \\
\text { title." }\end{array}$ & $\begin{array}{l}\text { Washington Constitution, } \\
\text { Article II, Section } 19\end{array}$ \\
\hline
\end{tabular}


Table 2. Classification of Initiatives by Ideology

An asterisk indicates subjects for which the classification is arguable.

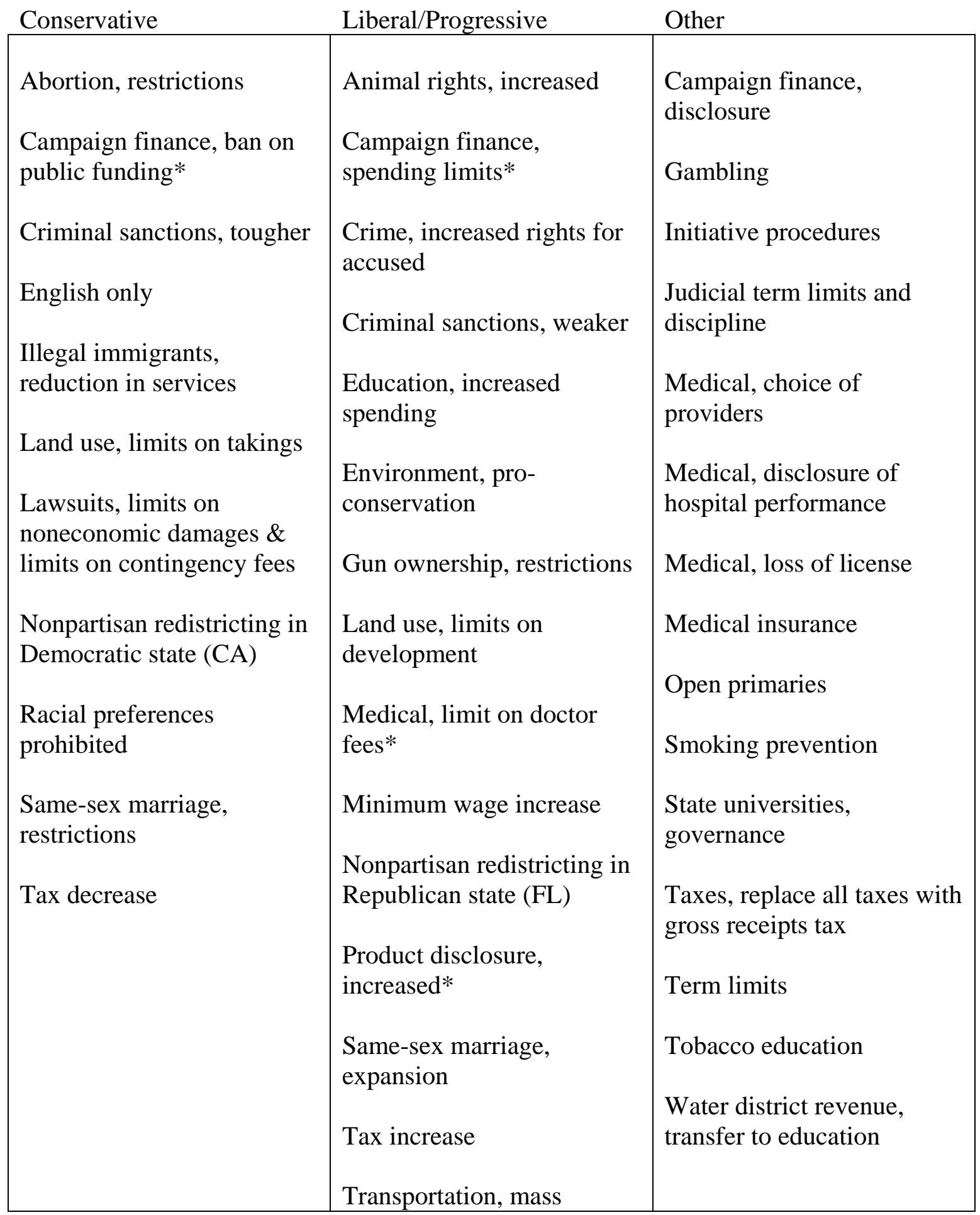




\section{Table 3. Summary Statistics on Judges}

This table reports summary statistics where the unit of observation is a judge. AGREE is equal to one if (i) the judge is a Democrat and the initiative is liberal/progressive, or (ii) the judge is a Republican and the initiative is conservative. The sample covers the period 1997-2006 and the states of California, Colorado, Florida, Oregon, and Washington.

\begin{tabular}{|c|c|c|c|c|c|}
\hline & Mean & SD & Min & Max & $\mathrm{N}$ \\
\hline $\begin{array}{l}\text { Dummy = } 1 \text { if judge votes to } \\
\text { uphold }\end{array}$ & 0.69 & 0.46 & 0 & 1 & 778 \\
\hline Number of words in initiative & 5,626 & 9,058 & 12 & 31,942 & 634 \\
\hline Year of decision & 2001.25 & 2.67 & 1997 & 2006 & 778 \\
\hline Dummy = 1 if judge Republican & 0.31 & 0.46 & 0 & 1 & 742 \\
\hline $\begin{array}{l}\text { Dummy }=1 \text { if conservative } \\
\text { initiative }\end{array}$ & 0.56 & 0.50 & 0 & 1 & 778 \\
\hline Dummy = 1 if liberal initiative & 0.24 & 0.43 & 0 & 1 & 778 \\
\hline $\begin{array}{l}\text { AGREE: Dummy = } 1 \text { if initiative } \\
\text { agrees with judge's party }\end{array}$ & 0.42 & .49 & 0 & 1 & 742 \\
\hline $\begin{array}{l}\text { DISAGREE: Dummy = } 1 \text { if } \\
\text { initiative disagrees with judge's } \\
\text { party }\end{array}$ & 0.38 & 0.49 & 0 & 1 & 742 \\
\hline Age of judge & 56.5 & 7.0 & 41 & 87 & 704 \\
\hline Years to next election & 2.9 & 2.8 & 0 & 12 & 764 \\
\hline
\end{tabular}




\section{Table 4. Percent of Decisions that Upheld Initiative}

The number of cases is reported in square brackets. Data cover the period 1997-2006.

\begin{tabular}{|c|c|c|c|}
\hline & Supreme Courts & $\begin{array}{c}\text { Intermediate } \\
\text { Appellate Courts }\end{array}$ & $\begin{array}{c}\text { Supreme }+ \\
\text { Intermediate Courts }\end{array}$ \\
\hline California & $\begin{array}{l}33 \\
{[3]}\end{array}$ & $\begin{array}{c}98 \\
{[46]}\end{array}$ & $\begin{array}{c}94 \\
{[49]}\end{array}$ \\
\hline Colorado & $\begin{array}{c}50 \\
{[32]}\end{array}$ & $\cdots$ & $\begin{array}{c}50 \\
{[32]}\end{array}$ \\
\hline Florida & $\begin{array}{c}79 \\
{[29]}\end{array}$ & $\begin{array}{l}100 \\
{[1]}\end{array}$ & $\begin{array}{c}80 \\
{[30]}\end{array}$ \\
\hline Oregon & $\begin{array}{c}43 \\
{[7]}\end{array}$ & $\begin{array}{c}0 \\
{[5]}\end{array}$ & $\begin{array}{c}25 \\
{[12]}\end{array}$ \\
\hline Washington & $\begin{array}{c}67 \\
{[6]}\end{array}$ & $\begin{array}{c}96 \\
{[28]}\end{array}$ & $\begin{array}{c}91 \\
{[34]}\end{array}$ \\
\hline TOTAL & $\begin{array}{c}62 \\
{[78]}\end{array}$ & $\begin{array}{c}91 \\
{[80]}\end{array}$ & $\begin{array}{c}76 \\
{[157]}\end{array}$ \\
\hline
\end{tabular}




\section{Table 5. Percent of Unanimous Decisions}

The number of cases is reported in square brackets. Data cover the period 1997-2006.

\begin{tabular}{lccc} 
& Supreme Courts & $\begin{array}{c}\text { Intermediate } \\
\text { Appellate Courts }\end{array}$ & $\begin{array}{c}\text { Supreme + } \\
\text { Intermediate Courts }\end{array}$ \\
\hline California & 33 & 96 & 92 \\
& {$[3]$} & {$[46]$} & {$[49]$} \\
Colorado & 75 & & 75 \\
& {$[32]$} & $\ldots$ & {$[32]$} \\
Florida & 66 & & 67 \\
& {$[29]$} & 100 & {$[30]$} \\
Oregon & 57 & {$[1]$} & 67 \\
& {$[7]$} & 80 & {$[12]$} \\
Washington & 17 & {$[5]$} & 85 \\
& {$[6]$} & 100 & {$[34]$} \\
\hline \multirow{2}{*}{ TOTAL } & 64 & {$[28]$} & 80 \\
& {$[78]$} & 96 & {$[157]$}
\end{tabular}




\section{Table 6. Logistic Regressions Predicting Vote of Individual Judges}

Each column reports estimates from a logistic regression that predicts the probability that a judge votes to uphold the initiative and reject the single subject challenge. Standard errors are in parentheses beneath coefficient estimates. All regressions include state-specific dummy variables for California, Colorado, Florida, Oregon, and Washington. The estimates in columns (4) and (5) exclude observations in which the initiative does not have a partisan orientation. The data cover the period 1997-2006. Significance levels are indicated: $*=10 \%, * *=5 \%, * * *=1 \%$.

\begin{tabular}{|c|c|c|c|c|c|}
\hline & $(1)$ & (2) & (3) & (4) & (5) \\
\hline $\begin{array}{l}\text { Words: Dummy = } 1 \text { if number of words greater } \\
\text { than median for state }\end{array}$ & $\begin{array}{l}1.04^{* * *} \\
(0.20)\end{array}$ & $\begin{array}{l}0.69^{* * *} \\
(0.22)\end{array}$ & $\begin{array}{l}0.68 * * * \\
(0.23)\end{array}$ & $\begin{array}{l}0.45^{*} \\
(0.27)\end{array}$ & $\begin{array}{c}0.43 \\
(0.27)\end{array}$ \\
\hline Year & $\begin{array}{l}0.12^{* * *} \\
(0.04)\end{array}$ & $\begin{array}{l}0.08^{* *} \\
(0.04)\end{array}$ & $\begin{array}{l}0.10^{* *} \\
(0.04)\end{array}$ & $\begin{array}{l}0.10^{* *} \\
(0.05)\end{array}$ & $\begin{array}{l}0.10^{* *} \\
(0.05)\end{array}$ \\
\hline $\begin{array}{l}\text { Dummy }=1 \text { if supreme court }(0=\text { intermediate } \\
\text { court of appeals) }\end{array}$ & $\ldots$ & $\begin{array}{l}-2.10^{* * * *} \\
(0.48)\end{array}$ & $\begin{array}{l}-2.43^{* * * *} \\
(0.56)\end{array}$ & $\begin{array}{l}-2.22^{* * *} \\
(0.69)\end{array}$ & $\begin{array}{l}-2.15^{* *} \\
(0.68)\end{array}$ \\
\hline $\begin{array}{l}\text { Dummy }=1 \text { if judge is Republican ( } 0 \text { if } \\
\text { Democrat) }\end{array}$ & $\ldots$ & $\begin{array}{c}0.35^{*} \\
(0.27)\end{array}$ & $\begin{array}{c}0.10 \\
(0.28)\end{array}$ & $\begin{array}{c}0.35 \\
(0.32)\end{array}$ & $\begin{array}{c}0.43 \\
(0.33)\end{array}$ \\
\hline Dummy $=1$ if conservative initiative & $\ldots$ & $\begin{array}{l}-0.72^{* * *} \\
(0.23)\end{array}$ & $\begin{array}{l}-0.41 \\
(0.25)\end{array}$ & $\begin{array}{c}-1.06^{* * *} \\
(0.33)\end{array}$ & $\begin{array}{l}-0.95^{* * *} \\
(0.35)\end{array}$ \\
\hline Dummy $=1$ if initiative concerns judiciary & $\ldots$ & $\begin{array}{l}-0.66^{*} \\
(0.40)\end{array}$ & $\begin{array}{c}0.00 \\
(0.44)\end{array}$ & $\begin{array}{l}-0.54 \\
(0.51)\end{array}$ & $\begin{array}{l}-0.38 \\
(0.53)\end{array}$ \\
\hline Age of judge & $\ldots$ & $\begin{array}{l}\cdots \\
\cdots\end{array}$ & $\begin{array}{c}-0.03^{*} \\
(0.02)\end{array}$ & $\begin{array}{l}-0.03^{*} \\
(0.02)\end{array}$ & $\begin{array}{c}-0.03^{*} \\
(0.02)\end{array}$ \\
\hline Years to next election & $\ldots$ & $\ldots$ & $\begin{array}{l}-0.07 \\
(0.05)\end{array}$ & $\begin{array}{l}-0.01 \\
(0.06)\end{array}$ & $\begin{array}{l}-0.002 \\
(0.06)\end{array}$ \\
\hline $\begin{array}{l}\text { AGREE: Dummy = } 1 \text { if conservative initiative } \\
\text { and Republican judge, or liberal initiative } \\
\text { and Democratic judge }\end{array}$ & $\ldots$ & $\cdots$ & $\begin{array}{l}1.21^{* * *} \\
(0.21)\end{array}$ & $\begin{array}{l}0.70^{* *} \\
(0.31)\end{array}$ & $\cdots$ \\
\hline $\begin{array}{l}\text { AGREE in "aggressive" states: Dummy = } 1 \text { if } \\
\text { AGREE and state is Colorado, Florida, or } \\
\text { Oregon }\end{array}$ & $\ldots$ & $\ldots$ & $\ldots$ & $\ldots$ & $\begin{array}{l}0.93^{* *} \\
(0.39)\end{array}$ \\
\hline $\begin{array}{l}\text { AGREE in "restrained" states: Dummy =1 if } \\
\text { AGREE and state is California or } \\
\text { Washington }\end{array}$ & $\ldots$ & $\cdots$ & $\cdots$ & $\cdots$ & $\begin{array}{c}0.26 \\
(0.54)\end{array}$ \\
\hline Observations & 634 & 628 & 599 & 509 & 509 \\
\hline
\end{tabular}


Table 7. Percent of Judges Voting to Uphold in Aggressive and Restrained States This table reports the percentage of judges voting to uphold, conditional on whether they "agree" or "disagree" with the policy of the initiative, and conditional on whether the state has an "aggressive" or "restrained" approach to the single subject rule. Initiatives are classified ideologically as in Table 2. The number of observations is in square brackets. Data cover the period 1997-2006.

\begin{tabular}{ccc}
$\begin{array}{c}\text { States with } \\
\text { "restrained" } \\
\text { enforcement }\end{array}$ & $\begin{array}{c}\text { States with } \\
\text { "aggressive" } \\
\text { enforcement }\end{array}$ & $\begin{array}{c}\text { All states } \\
\text { together }\end{array}$ \\
(CA, WA) & (CO, FL, OR) & \\
\hline
\end{tabular}

AGREE: Democratic judge and progressive initiative, or

Republican judge and

conservative initiative

DISAGREE: Democratic judge and conservative initiative, or

progressive initiative 